JOURNAL OF EDUCATIONAL REVIEW AND RESEARCH

e-ISSN: 2597-9752 dan p-ISSN: 2597-9760

This work is licensed under

a Creative Commons Attribution-NonCommercial 4.0 International License.

\title{
The Effect of the Scientific Approach with Comic Intelligent Media Support on Students' Science Competencies
}

\author{
Nandang Hidayat ${ }^{1}$, Teti Rostikawati ${ }^{2}$ \\ Program of Biology Education, Faculty of Teacher Training and Education, Pakuan University, \\ Bogor, Indonesia ${ }^{1,2}$ \\ mr.nandanghidayat@gmail.com ${ }^{1}$,tetirostikawati@gmail.com²
}

\section{Keywords :}

science competence, scientific approach, comic media,

learning process

\begin{abstract}
This study aims to test the effectiveness of the use of intelligent comic media combined with the process of learning with scientific approach onstudents' science competence. The research method used is quasi experimental method with $2 \times 2$ factorial design. The study involved four teachers and 112 students of grade 4 from SDN Pertiwi, SDN Polisi 1, SDN Kebon Pedes 1, and SDN Kebon Pedes 5 in Bogor city. The study was conducted in the first half of the academic year 2014/2015. This study concludes that the use of intelligent comics combinedunitedly in the learning process with scientific approach significantly influence the science competence of grade 4 elementary school students on the aspects of knowledge and scientific attitude, but does not significantly affect the competence of science for the aspects of science process skills. This study also concludes that there is no interaction between the learning process as the treatment variable and the involvement of the students in the out-of-school learning guidance (tutorial) as the moderator variable. That is, the influence of the learning process on the students'competence of science on aspects of knowledge and scientific attitudes are not contaminated by the involvement of the students in the guidance of learning.
\end{abstract}

\section{INTRODUCTION}

\section{Background of the Study}

The era of globalization is the era of information which is characterized by rapid change, uncertainty, and opportunities for competition to occur at the inter-individual level. The era of globalization opens up opportunities as well as challenges for competitive individuals and full of initiatives, but it will be disastrous for those who do not have the required competencies.

To prepare young generations of Indonesian nation to enter the globalization era, education plays a very strategic role. Through appropriate educational practices, we can empower and develop the students' competencies in order to compete in the global era. One of the efforts to achieve this is by continually improving the national curriculum. In 2013, Indonesia developed a curriculum tailored to 
the demands of human life in a global era called Curriculum Year 2013. The 2013 Indonesia National Curriculum, has different characteristics from the previous curriculum. The National Curriculum is more process-oriented, i.e. thematic, contextual, and integrative-based learning process.

Each curriculum has different characteristics that require the teacher to understand it and implement it in the learning practice. However, in reality curriculum changes do not necessarily change the attitude and behavior of teachers in carrying out their duties. Many teachers are less concerned with the changes of curriculum and the changes that occur in society. They tend to maintain a routine learning model.This can be seen from the teachers'behavior when carrying out learning activities.

The inherent conception of the teacher's mind about the nature of science will influence the way the teacher teaches it, because the purpose of science learning set will depart from the essence of science that is believed. What students will gain from the teacher in science learning depends on the teacher's beliefs about the soul, structure and function of science. If science is viewed as a collection of facts, generalizations, concepts, principles, theories, and laws, then it will teach science by asking students to remember them all. When teachers view science as a process or method of investigating problems with objects, natural events, and interconnectedness between them, they will teach science by engaging children in various scientific processes to solve problems. Therefore, teachers need to understand the true nature of science.

Science is a series of conceptual and conceptual schemes that have been developed as a result of experiments and observations that encourage experimentation and further observation (Conant, James, B., 1951). So science is a process of learning by humans to study natural phenomena resulting in a collection of facts that lead to the discovery of various concepts, principles, generalizations, theories, and laws about nature as a form of science products. Facts gathering is done through a process that is a scientific method that requires the possession of scientific process skills and scientific attitudes that allow both to grow along with the development of human understanding of nature. In relation to the learning process, the "science" label is used to refer to a diverse collection of learning and learning content (Dorph, Rena, Cannady, Matthew A., \& Schunn, Christian, 2016).

The scientific approach is not a simple approach, but is an activity of inquiry where students make observations, ask questions, use evidence to explain questions, use tools to collect, process and interpret data, and communicate findings. Inquiry is a series of activities, depending on the level of student involvement in asking and answering questions. This can range from simple inquiries involving a lot of teacher guidance, to an open investigation where student engagement is very high (Newman, W, Abell, S., Hubbard, P., McDonald, J., Otaala, J., \& Martini, M., 2004). Inquiry-based learning is an active, student-centered approach that involves questions, critical thinking, and problem solving (Perrin, Michele, 2004). The Indonesian National Curriculum 2013 calls it scientific approach involving observing, questioning, reasoning, trying, and communicating activities or networking for all subjects (Kementerian Pendidikan dan Kebudayaan, 2013), (Badan Standar Nasional Pendidikan, 2013).

Some authors describe the inquiry method as a series for classroom science that enable teachers to choose the level of student involvement in the learning process (Bell, R. L., Smetana, L., \& Binns, I., 2005), (Colburn, A., 2004), (Windschitl, M., 2002). Inquiry-based learning aims to enable students to become active learners by participating in discussions, forming opinions, solving problems, and following guided investigations. The teacher's role in this method is to act as a facilitator rather than an ordinary teacher in a class that makes all decisions that give little freedom to students (Bruner, J., 1965). Inquiry approach can be the key factor of teacher's success in science learning process (Bhattacharyya, S., Mead, Tim P., Junot, M., \& Welch, Adam., 2013).

Chemistry is one content of teaching materials in science. The laboratory approach is considered an integral element of chemical education, and students who follow laboratory instruction based on constructivist theory show higher achievement values, deeper attention, and more frequent participation in chemistry courses (Duffy, T. M., \& Jonassen, D. H., 1991), (Celikler, D., Gunes M. 
H., \& Sendil, K., 2006), (Tatli, Z. \& Ayas, A., 2011)., but a learning environment adopting and implementing constructivist learning theories must be supported by activities that facilitate cooperation and interactions that require more time (Koseoglu, F., \& Tumay, H., 2010). Similar events are suspected to occur in the whole science materials.

Media in learning is a tool to deliver information. The medium is used as "the way instructional messages are communicated to students" (Smith, P.I. \& Ragan, T.J., 2005).. Within the learning environment, teacher delivers instruction using the media made available. People do not interact or collaborate with media, they interact or collaborate with other people, and this often occurs through media (Kozma, R. B., 1991).Students are not affected by the media, but by how the instruction is designed to take advantage of various media features. As the development of media tools, understanding of the factors that affect its utilization still requires development. The use of media makes a difference how to design teaching, create efficiencies in delivery and assessment, and facilitate information processing. This is a valuable tool, but it's just a tool that provides channels for content delivery and exchange (Arnold, B., 2015).

From several theoretical studies and research results it appears that the learning media will not be useful if it is not combined well with the approach or learning method used. Learning media will not help improve the quality of students' learning process and learning outcomes if their use does not blend with the learning method. On the basis of such thinking, this experimental study was designed. In this study, the implementation of the scientific approach suggested by the Indonesian National Curriculum 2013 is combined with the use of intelligent comic learning media (ICM). ICMwas developed with the reference to the content of science materials in accordance with the themes of science learning for elementary school grade 4 in the Indonesian National Curriculum 2013.

\section{Research Problems}

This study examines "How is the influence of scientific approach combined with ICMon the achievement of science competence of grade $4^{\text {th }}$ elementary school students?"

\section{Purpose}

The main purpose of this research is to investigate the influence of scientific approach combined with the presentation of teaching materials in the form of ICM on the science competence of grade $4^{\text {th }}$ elementary school students for the learning themes in semester 1 .

\section{METHOD}

\section{Material}

The following steps are used to develop ICM. First, identifying the themes of science learning grade 4 of elementary school semester 1 . The results of the identification obtained four learning themes on the subjects of science, namely (1) Beautifulness Togetherness, (2) Always Energy Saving, (3) Caring for Living Beings, and (4) Various Work. This data are supported by literature in the form of national curriculum year 2013, textbooks for students, and teacher handbooks (Kementerian Pendidikan dan Kebudayaan Republik Indonesia, 2013). Second, developing ICM for the four themes above. ICM development is assisted by five lecturers at the Biology Education Study Program, Faculty of Teacher Training and Education, Pakuan University. Third, the ICM that has been completed is subsequently tested for validity which includes: the accuracy, completeness and adequacy of the content, and its readability through the judgment by science experts and media learning experts. Fourth, a trial through peer teaching involving four teachers from the four primary schools who became the research site. The trial was done in Pakuan University. Through these steps, it was proven that the products of four ICM are theoretically valid, and will be tested for empirical effectiveness through this research. The four ICM are presented in the following figure. 


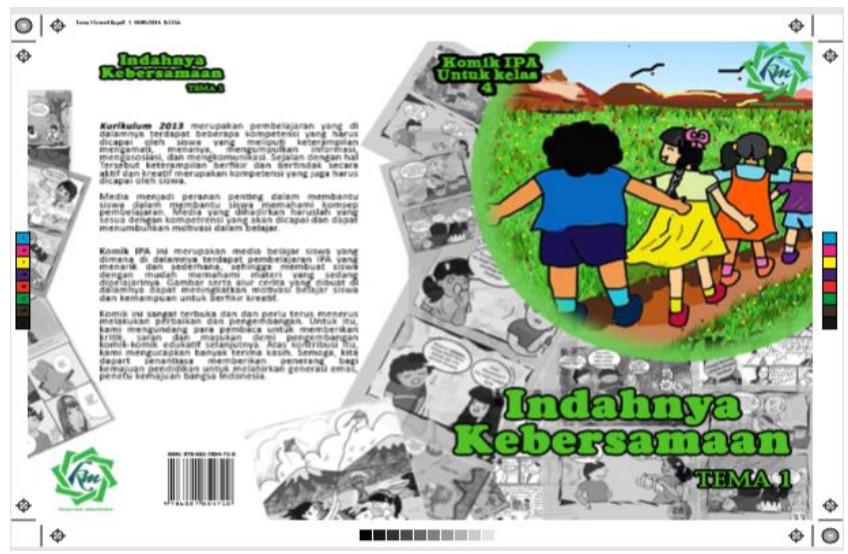

Fig. 1 ICM Theme 1

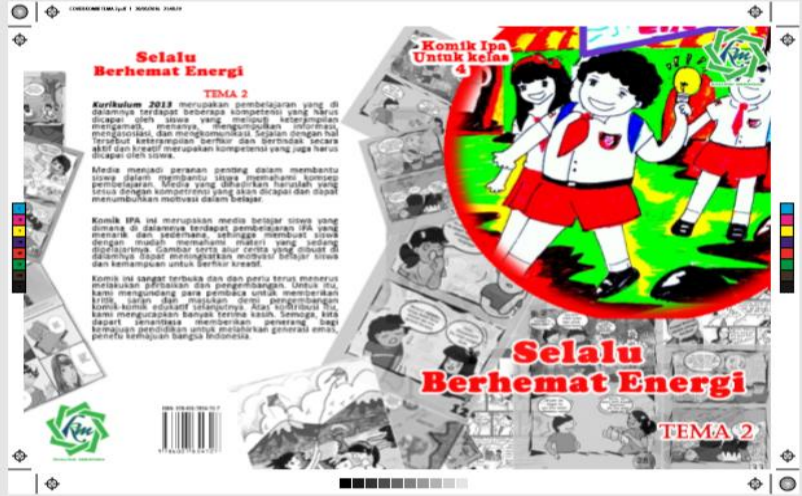

Fig. 2 ICM Theme 2

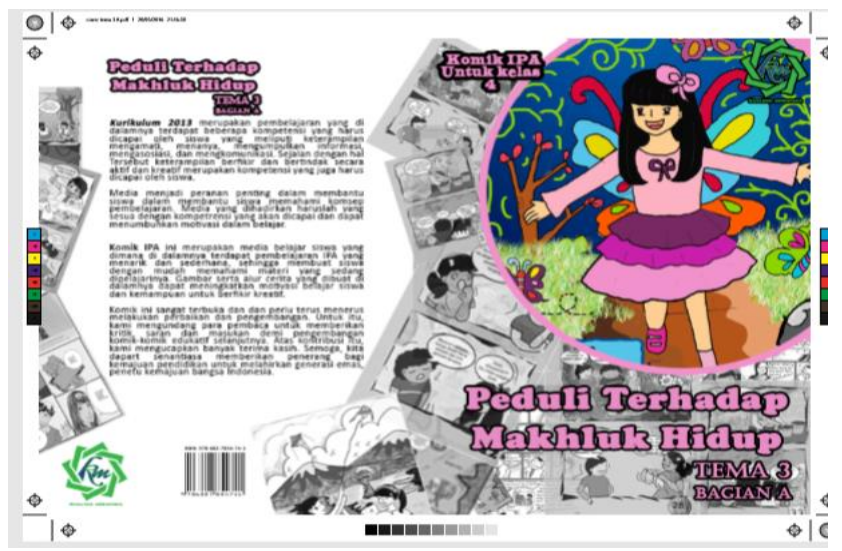

Fig. 3 ICM Theme 3

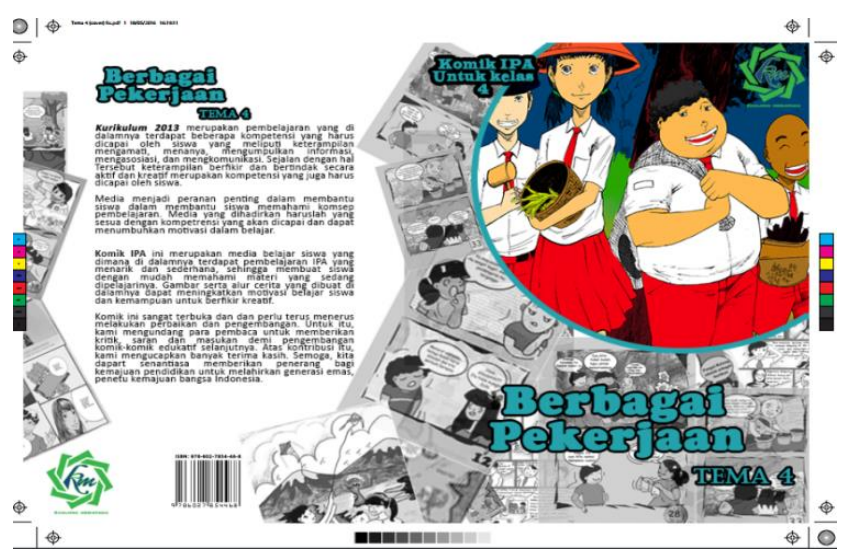

Fig. 4 ICM Theme 4 
The four ICMs were then used as a science learning media in four elementary schools in Bogor city, West Java, Indonesia, namely SDN Pertiwi, SDN Polisi 1, SDN Kebon Pedes 1, and SDN Kebon Pedes 5. The four schools were randomly selected from all primary schools in Bogor city that had implemented the 2013 national curriculum.

\section{Research Design}

This research uses quasi experimental method with $2 \times 2$ factorial design. As independent variable is student's science competence, treatment variable is learning process using scientific approach combined with Intelligent Comic learning Media $(\mathrm{SA}+\mathrm{ICM})$ as experiment group and scientific approach without Intelligent Comic learning Media (SA) as control group, while moderator variable is students' participation in learning guidance (tutorial) outside the school. The research design is presented in Table 1.

Table 1. Research Design

\begin{tabular}{ccc}
\hline Tutorial & \multicolumn{2}{c}{ Learning Process } \\
\cline { 2 - 3 } & SA+ICM & SA \\
\hline Participate & 29 & 30 \\
Do not Participate & 29 & 24 \\
Total & 58 & 54 \\
\hline
\end{tabular}

\section{Sample}

The sample group consisted of four class teachers with civil servant status (PNS) and experienced teaching in primary schools for more than 10 years and 112 students from four elementary schools, as shown in table 1. To check the quality and function of ICM developed, in-depth interviews were conducted to participating teachers. Participating students are all students enrolled in each elementary school. The experimental group is the students who follow the learning process of SA + ICM, the students at SDN Pertiwi 1 and SDN Kebon Pedes 1 with $n=58$, while the control group are the students who follow the SA learning process, SDN Polisi 1 and SDN Kebon Pedes 5 with $n=54$. The experimental groups in each school followed the learning process using a scientific approach combined with ICM. The control group is not manipulated, in each school the students follow the learning process using scientific approach without being combined with ICM. Each teacher is observed by one researcher at each learning session.

\section{Instruments for Data Collection}

The instrument of data collection in this research is Science Competence Test(SCT) covering knowledge aspect (SCT-1), science process skill (SCT-2), and scientific attitude (SCT-3), semi structured interview, and unstructured observation. CST-1 consists of 40 multiple-choice test items with three options that measure the competence of the knowledge aspects relating to the learning themes (Kementerian Pendidikan dan Kebudayaan Republik Indonesia, 2013). SCT-2 consists of 20 basic science skill test items with three rating scales that include observing skills, classifying, predicting, measuring, drawing conclusions, and communicating (Carin, Arthur A. and Robert B. Sund., 1975), (Funk, H. James, et al., 1979). SCT-3 consists of 20 items of attitude scale measurement with three rating scales that include curiosity, skepticism, humility, objectivity, openness and honesty (Carin, Arthur A. and Robert B. Sund., 1975). Prior to use in the research, the three instruments were tested first to test their validity and reliability, and all of them were valid and reliable.

\section{Research Procedure}

The study was conducted in one semester of academic year 2014/2015 and was conducted in four elementary schools in Bogor city. The experimental and control groups were randomly selected from all primary schools in Bogor city that had implemented the 2013 curriculum. However, because group manipulation is not possible (i.e. students enrolled into related classes), this study used quasi experimental methods. Quasi-experimental methods were used in this study because it was not possible to select a completely random sample (Cohen, L. \& Manion, L., 1994), this design was used in circumstances where it was not possible to randomize individuals or groups (McMillan, J. H., \& Schumacher, S., 2006). The data were collected using SCT at the beginning and at the end of the learning process on each learning theme as a pre-test and post-test of student achievement. The 
implementation process and the instruments used are summarized in Table 2.

Table 2. The Process of Research Implementation

\begin{tabular}{cccc}
\hline $\begin{array}{c}\text { Group of } \\
\text { each school }\end{array}$ & $\begin{array}{c}\text { Data collection before treatment } \\
\text { (SCT-1, SCT-2, and SCT-3) }\end{array}$ & Process & $\begin{array}{c}\text { Data collection after treatment } \\
\text { (SCT-1, SCT-2, and SCT-3) }\end{array}$ \\
\hline SA+ICM & $\mathrm{x}$ & $*$ & $\mathrm{x}$ \\
SA & $\mathrm{x}$ & $* *$ & $\mathrm{x}$ \\
\hline
\end{tabular}

Notes:

* Teachers perform the learning process using a scientific approach combined with ICM. Students' behavior during the learning process is observed with an unstructured form of observation.

** Teachers perform the learning process using a scientific approach without the support ICM.Students' behavior during the learning process is observed by one of the researchers with unstructured observation.

\section{Data Analysis}

To test whether the SCT score of the experimental group with the control group before and after the learning process differented significantly in the paired sample, two-way ANOVA techniques were used (Kadir, 2016). The data analyzed is the normalized gain ( $\mathrm{N}$-gain) data of pre-test and post-test results.The SPSS 24.0 statistical application program was used to help analyze the data. In addition, observation and interview data were used to support quantitative data.

\section{RESULTS AND DISCUSSIONS}

A. Result

1. Students' Science Competence Knowledge Aspect

Descriptive statistics of students' science competency data for knowledge aspect are presented in table 3.From the table it appears that the group of students who follow the learning process of SA + ICM and follow the tutorial outside school hours, achieve the average $\mathrm{N}$-gain science competence on the knowledge aspect of 19.52, while the group of students who did not follow the tutorial outside school hours achieved 18.38, and the overall average is 18.95. Meanwhile, the group of students who follow the SA learning process and the tutorial outside school hours, achieve the average N-gain of science competence on the knowledge aspect of 18.27, while the group of students who did not follow the tutorial outside the school hours was 15.21, and an overall average of 16.91. Overall, regardless of the learning process, the average $\mathrm{N}$-gain of science competence of the students who followed the tutorial outside school hours was 18.88 , while the group of students who did not follow the tutorial was 16.94. Average N-gain students' science competencies regardless of learning process and participation in tutorial as 17.96 .

Table 3. Descriptive Statistics

\begin{tabular}{|c|c|c|c|c|}
\hline \multicolumn{5}{|c|}{ Dependent Variable: SSC Knowledge Aspect } \\
\hline Learning Process & Tutorial & Mean & Std. Deviation & $\mathbf{N}$ \\
\hline \multirow{3}{*}{$\mathrm{SA}+\mathrm{ICM}$} & Participate & 19.52 & 4.572 & 29 \\
\hline & Do not Participate & 18.38 & 4.625 & 29 \\
\hline & Total & 18.95 & 4.594 & 58 \\
\hline \multirow[t]{3}{*}{ SA } & Participate & 18.27 & 3.814 & 30 \\
\hline & Do not Participate & 15.21 & 4.075 & 24 \\
\hline & Total & 16.91 & 4.186 & 54 \\
\hline \multirow[t]{3}{*}{ Total } & Participate & 18.88 & 4.214 & 59 \\
\hline & Do not Participate & 16.94 & 4.626 & 53 \\
\hline & Total & 17.96 & 4.500 & 112 \\
\hline
\end{tabular}

Although it cannot be drawn conclusions related to the influence of the learning process and students' involvement in the guidance on the average $\mathrm{N}$-gain students' science competencies, but based on the descriptive statistics obtained the picture that the average $\mathrm{N}$-gain achieved between groups of students 
tend to be different.

The result of inferential statistical analysis of $\mathrm{N}$-gain data of science competence of student of knowledge aspect with two-way ANOVA technique is presented in table 4. The correction test of the influence of the treatment variables, the learning process, the participation in the tutorial, and the interaction of the learning process with the participation of tutorial on the $\mathrm{N}$-gain of students science competence on the knowledge aspect shows that the parameter $\mathrm{F}=4.708$ with $\mathrm{p}$-value $=0.04<0.05$. That is, the model obtained is valid.

Table 4. Between-Subjects Effects Test

Dependent Variable: SSC Knowledge Aspect

\begin{tabular}{cc|c|c|c|c}
\hline Source & Type III Sum of Squares & df & Mean Square & F & Sig. \\
\hline Corrected Model & $259.963^{\mathrm{a}}$ & 3 & 86.654 & 4.708 & .004 \\
\hline Intercept & 35382.767 & 1 & 35382.767 & 1922.305 & .000 \\
\hline Learning Process & 135.797 & 1 & 135.797 & 7.378 & .008 \\
\hline Tutorial & 122.311 & 1 & 122.311 & 6.645 & .011 \\
\hline Learning Process * Tutorial & 25.617 & 1 & 25.617 & 1.392 & .241 \\
\hline Error & 1987.894 & 108 & 18.406 & & \\
\hline Total & 38392.000 & 112 & & & \\
\hline Corrected Total & 2247.857 & 111 & & & \\
\hline
\end{tabular}

R Squared $=.116$ (Adjusted R Squared $=.091$ )

Based on table 4, to test the influence of learning process on students' science competence on knowledge aspect, it appears that the value of $\mathrm{F}$ for learning process variable is 7.378 for $\mathrm{p}$-value $=$ $0.008<0.05$. That is, there is an average difference of $\mathrm{N}$-gain of science competence on significant knowledge aspect between the students who follow SA + ICM review process with the students who follow SA learning process without being combined with ICM. To test the influence of students' participation in the tutorial on the students' science competence on the knowledge aspect obtained the result, the $\mathrm{F}$ value for student participation variable in the tutorial is 6.645 for $\mathrm{p}$-value $=0.011<$ 0.05.Thus, there is an average difference of $\mathrm{N}$-gain of science competence on the significant knowledge aspect between students who follow the tutorial with the students who do not participate. Meanwhile, $\mathrm{F}$ value for interaction between learning process variable with students' participation in tutorial is 1.392 for $\mathrm{p}$-value $=0.241>0.05$. Thus, there is no interaction between the learningprocesses with the participation of students in the tutorial of students' science competencies on the knowledge aspect. Thus, it is not necessary to continue with a two-way Post Hoc ANOVA trial.

\section{Students' Science Competence Science Process skill Aspect}

Descriptive statistics of students' science competency data for aspects of science process skills are presented in table 5 .

Table 5. Descriptive Statistics

\begin{tabular}{c|cc|c|c}
\hline \multicolumn{3}{c}{ Dependent Variable: SSC Science Process Skills Aspect } \\
\hline Learning Process & Tutorial & Mean & Std. Deviation & N \\
\hline SA + ICM & Participate & 8.00 & 2.739 & 29 \\
\cline { 2 - 5 } & Do not Participate & 9.14 & 2.787 & 29 \\
\cline { 2 - 5 } & Total & 8.57 & 2.798 & 58 \\
\hline \multirow{3}{*}{ SA } & Participate & 8.80 & 2.759 & 30 \\
\cline { 2 - 5 } & Do not Participate & 9.29 & 2.349 & 24 \\
\cline { 2 - 5 } & Total & 9.02 & 2.573 & 54 \\
\hline \multirow{2}{*}{ Total } & Participate & 8.41 & 2.755 & 59 \\
\cline { 2 - 5 } & Do not Participate & 9.21 & 2.575 & 53 \\
\cline { 2 - 5 } & Total & 8.79 & 2.689 & 112 \\
\hline
\end{tabular}

From table 5 it appears that the group of students who follow the learning process of SA + PA and follow the tutorial activities outside school hours, achieve the average $\mathrm{N}$-gain science competence on 
the aspects of science process skills of 8.00, while the group of students who do not follow the tutorial activities outside school hours is 9.14, and an overall average is 8.57. Meanwhile, the group of students who follow the SA learning process and follow the tutorial activities outside school hours, achieve the average of $\mathrm{N}$-gain science competence on the science skills aspect of 8.80 , while the group of students who do not follow the tutorial activities outside school hours 9.29, and an overall average of 9.02. Overall, regardless of the process of science learning, students who follow the tutorial activities outside the school, obtained the average $\mathrm{N}$-gain science competence on the aspects of science process skills of 8.41, while the group of students who did not follow the tutorial of 9.21, while the overall average without considering the independent variable is 8.79.

The result of inferential statistical analysis of $\mathrm{N}$-gain data of science competence of students of science process skill aspect with two-way ANOVA technique is presented in Table 6.

Table 6. Between-Subjects Effects Test

\begin{tabular}{cc|c|c|c|c}
\hline \multicolumn{7}{c}{ Dependent Variable: } & SSC Science Process Skills Aspect & & \\
\hline Source & Type III Sum of Squares & df & Mean Square & F & Sig. \\
\hline Corrected Model & $27.651^{\mathrm{a}}$ & 3 & 9.217 & 1.284 & .284 \\
\hline Intercept & 8620.985 & 1 & 8620.985 & 1201.056 & .000 \\
\hline Learning Process & 6.318 & 1 & 6.318 & .880 & .350 \\
\hline Tutorial & 18.446 & 1 & 18.446 & 2.570 & .112 \\
\hline Learning Process * Tutorial & 2.901 & 1 & 2.901 & .404 & .526 \\
\hline Error & 775.207 & 108 & 7.178 & & \\
\hline Total & 9448.000 & 112 & & & \\
\hline Corrected Total & 802.857 & 111 & & & \\
\hline
\end{tabular}

R Squared $=.034$ (Adjusted R Squared $=.008)$

From table 6, it appears that for correction test of model of influence of treatment variable that is learning process, tutorial participation, and interaction of learning process with the participation of tutorial toward $\mathrm{N}$-gain students science competence on science skills aspect show that parameter $\mathrm{F}=$ 1.284 with p-value $=0.284>0.05$. That is, the model obtained is invalid. The test of the influence of the learning process on the students' science competence on the aspects of science process skills show that the value of $\mathrm{F}$ for learning process variables is 0.880 with $\mathrm{p}$-value $=0.350>0.05$. That is, there is no difference of average $\mathrm{N}$-gain of science competence on aspects of science process skill between students who follow SA + ICM review process with students who follow SA learning process.To test the effect of students' participation variables in the tutorial, it appears that the value of $F$ for students' participation variables in the tutorial is 2.570 with $\mathrm{p}$-value $=0.112>0.05$. That is, there is no difference in the average $\mathrm{N}$-gain science competence on aspects of science process skills between students who follow the tutorial with students who do not follow the tutorial. Meanwhile, F value for interaction between learning process variable with student participation in tutorial is 0.404 with $\mathrm{p}$ value $=0.526>0.05$. That is, there is no interaction between the learning processes with the participation of students in the tutorial on the competence of science students on aspects of science process skills. Thus, it is not necessary to continue with a two-way Post Hoc ANOVA trial.

\section{Students' Science Competence Scientific Attitude Aspect}

Descriptive statistics of students' science competency data for aspects of scientific attitude are presented in table 7. From the table it appears that for the group of students who follow the SA + ICM learning process and follow the tutorial activities outside the school, achieve the average $\mathrm{N}$-gain science competence on the scientific attitude aspect of 11.45, while the group of students who do not follow the tutorial activities of 10,45, and an overall average of 10.95.Meanwhile, the group of students who follow the SA learning process and follow the tutorial activities outside the school, achieve the average $\mathrm{N}$-gain of science competence on the scientific attitude aspect of 9.53, while the group of students who did not follow the tutorial activities outside school was 7.33 , and an overall average of 8.56. Overall, regardless of learning process variables, the students who follow the tutorial activities outside the school, attained the average $\mathrm{N}$-gain science competence on the scientific attitude aspect of 10.47, while the group of students who did not follow the tutorial of 9.04, while the overall 
average without considering independent variable of 7.79 .

Table 7. Descriptive Statistics

\begin{tabular}{ccc|c|c}
\hline \multicolumn{4}{c}{ Dependent Variable: SSC Scirntific Attitude Aspect } \\
\hline Learning Process & Tutorial & Mean & Std. Deviation & $\mathbf{N}$ \\
\hline \multirow{3}{*}{ SA + ICM } & Participate & 11.45 & 4.469 & 29 \\
\cline { 2 - 5 } & Do not Participat & 10.45 & 4.041 & 29 \\
\cline { 2 - 5 } & Total & 10.95 & 4.253 & 58 \\
\hline \multirow{3}{*}{ SA } & Participate & 9.53 & 3.014 & 30 \\
\cline { 2 - 5 } & Do not Participat & 7.33 & 3.239 & 24 \\
\cline { 2 - 5 } & Total & 8.56 & 3.278 & 54 \\
\hline \multirow{2}{*}{ Total } & Participate & 10.47 & 3.888 & 59 \\
\cline { 2 - 5 } & Do not Participat & 9.04 & 3.985 & 53 \\
\cline { 2 - 5 } & Total & 9.79 & 3.982 & 112 \\
\hline
\end{tabular}

The result of inferential statistical analysis of $\mathrm{N}$-gain data of science competence of students of scientific attitude aspect with two-way ANOVA technique is presented in table 8.

Table 8. Between-Subjects Effects Tests

\begin{tabular}{cc|c|c|c|c}
\hline \multicolumn{7}{c}{ Dependent Variable: } & SSC Scientific Attitude Aspect & & \\
\hline Source & Type III Sum of Squares & df & Mean Square & F & Sig. \\
\hline Corrected Model & $239.132^{\mathrm{a}}$ & 3 & 79.711 & 5.659 & .001 \\
\hline Intercept & 10437.132 & 1 & 10437.132 & 741.028 & .000 \\
\hline Learning Process & 175.735 & 1 & 175.735 & 12.477 & .001 \\
\hline Tutorial & 71.128 & 1 & 71.128 & 5.050 & .027 \\
\hline Learning Process * Tutorial & 10.002 & 1 & 10.002 & .710 & .401 \\
\hline Error & 1521.145 & 108 & 14.085 & & \\
\hline Total & 12505.000 & 112 & & & \\
\hline Corrected Total & 1760.277 & 111 & & & \\
\hline
\end{tabular}

$\mathrm{R}$ Squared $=.136$ (Adjusted R Squared $=.112$

From the table it appears that the correction test for the influence of the treatment variables is the learning process, the participation of tutorial, and the interaction of the learning process with the participation of tutorial on the $\mathrm{N}$-gain of students science competence on the scientific attitude aspect shows that the parameter $\mathrm{F}=5,659$ with $\mathrm{p}$-value $=0.001<0.05$. That is, the model obtained is valid. The test of the influence of the learning process on students' science competence on the scientific attitude aspect shows that the value of $\mathrm{F}$ for learning process variable is 12.477 with $\mathrm{p}$-value $=0.001<$ 0.05 . That is, there is a difference of average $\mathrm{N}$-gain of science competence on aspects of scientific attitude between students who follow SA + ICM review process with students who follow SA learning process.

To test the influence of students' participation variables in the tutorial, it appears that the value of $F$ for students' participation variables in the tutorial of 5.050 with $p$-value $=0.027<0.05$. That is, there is a difference of average $\mathrm{N}$-gain competence of science on aspects of scientific attitude between students who follow tutorial with students who do not follow the tutorial. Meanwhile, the value of $F$ for the interaction between learning process variables with the participation of students in the tutorial of 0.710 with $\mathrm{p}$-value $=0.401>0.05$. That is, there is no interaction between the learning process and the participation of students in the tutorial on the competence of science students on aspects of scientific attitude. Thus, it is not necessary to continue with a two-way Post Hoc ANOVA trial.

\section{B. Discussion}

Two-way ANOVA is one of the parametric tests, used in this study because the required statistical assumptions are met, that is, the normal distributed $\mathrm{N}$-gain data, from the interval scale, and the variance is homogeny (Kadir, 2016). 
Based on the ANAVA summary presented in Table 4, it was found that science competence on knowledge aspect among students who follow SA + ICM learning process is significantly different from the students who follow SA learning process without being combined with ICM. In this case, the mean N-gain of students who follow SA + ICM review process is higher than the students who follow SA learning process. Also found that there is no interaction between the learning process and the students' involvement in the tutorial of science competence on the aspects of knowledge. That is, the learning process directly affects the students'competence of science on aspects of knowledge. These findings suggest that learning media will effectively function to increase students' involvement in the learning process when its use is combined in unity with the learning process [18] especially the learning process that refers to constructivist theories such as inquiry approach that leads students to learn through active experience (Fernando, Sithara YJN \& Marikar, Faiz MMT., 2017).

The results of this study indicate that the students prefer the application of learning that combines the blended between approach, method, and the use of learning media. Students' learning energy emerges positively. These findings are consistent with other findings in the context of similar problems (Alzahrani1, Majed G \& O’Toole, John M., 2017) despite their college locus (Ja'ashan, M. H., 2015), (Alseweed, M. A., 2013).

This research also finds that science competence in science skill aspect among the students who follow SA + ICM learning process with the students who follow SA learning process does not differ significantly, and there is no interaction between learning process with the student involvement in tutorial on science competence on aspects of science process skills (See table VI). These findings suggest that the use of ICM in the learning process does not effectively improve students' science process skills. ICM is a learning media that can motivate students extrinsically. Extrinsic motivation affects the achievement of early/younger grade students (Lemos, Marina S. \& Veríssimo, Lurdes V., 2014), in the knowledge aspect (Daşdemir, İkramettin., 2016), because of the spiral structure of the science curriculum in both the 2006 national curriculum and the 2013national curriculum, students have knowledge of the teaching materials units they learned previously. They follow the learning process with the background of that knowledge and the information they have learned from their environment (Novak, D. J., 1988). This is not the case with science competencies in the aspects of science process skills. Thus, this study shows that the use of ICM cannot motivate children to be more active in doing the activity so that there is an increase of science process skill.

The summary of ANAVA for scientific competency variable of scientific attitude aspect as presented in table 8 , found that the students' science competence on the aspects of scientific attitude among the students who follow SA + ICM learning process differ significantly with the students who follow SA learning process. In this case, the average $\mathrm{N}$-gain of students' science competencies on aspects of scientific attitudes that follow the SA + ICM review process is higher than the students who follow the SA learning process. It is also found that there is no interaction between the learning process with the involvement of students in the guidance to the competence of science on the aspects of scientific attitude. That is, the process of learning directly affects the competence of science students on aspects of scientific attitude. These findings indicate that ICM instructional media effectively improve students' involvement in learning process when the use of media is combined unitedly with learning process to increase student's scientific attitude. The results of this study are in line with other studies which show that the use of 5E instructional model enriched with cooperative learning and animation media can improve the academic achievement and scientific attitude of seventh grade students (Daşdemir, İkramettin., 2016).

The results of this study indicate that the science learning media presented in the form of pictorial comics can motivate students to increase the intense involvement in the learning process and activities at school. Involvement in school activities is an important construction since it has been shown to be positively related to students' achievement in school (You, S., \& Sharkey, J., 2009). Involvement as a multidimensional construction that includes three components of behavior, emotion and cognitive that interact in a complex and dynamic manner (Fredericks, J.A., Blumenfeld, P.C. \& Paris, A.H., 2004). The behavior dimension is related to participation in academic work and social or extracurricular 
activities, and in accordance with school and class rules. Emotional dimension refers to the affective experiences that occur in the classroom and in the school and the experience associated with creating affective bonds with teachers and peers. Meanwhile, the cognitive dimension is based on the idea of intellectual investment and effort to understand academic themes and to develop complex competencies (Archambault, I., Janosz, M., Morizot, J., \& Pagani, L., 2009).

Finally, the results of this study can be used as a basis of rational and empirical study related to the need to develop an interesting learning media, especially for elementary school students. This study proves that students become more motivated to engage intensively in learning activities so that their science competence achievement is higher, even for the scientific aspects of science process skills tested in this study.

\section{CONCLUSION AND SUGGESTION}

Based on the results of this study it can be concluded that the use of Intelligent Comics Media combined unitedly in the learning process with scientific approach significantly influence the competence of science of grade 4 students of primary school on the aspects of knowledge and scientific attitude, but did not significantly affect the competence of science for the aspect of process skills science. It is also concluded that there is no interaction between learning process as treatment variable with students' involvement in learning guidance as moderator variable. That is, the influence of the learning process on the competence of science students on aspects of knowledge and scientific attitudes are not contaminated by the involvement of students in tutorial activity outside the school.

The implication of this research result is Intelligent Comics Media that had been developed through this research need to be utilized as media in science learning process in grade 4 of primary school. Furthermore, it is necessary to do development research to produce Intelligent Comic Media for other classes or other creative media model.

\section{ACKNOWLEDGMENTS}

Special thanks are given to the Directorate of Research and Community Service, Ministry of Research and Higher Education of the Republic of Indonesia who has funded this research, fellow researchers, and colleagues who have helped the process of collecting the data. Special thanks go to the principals, teachers and students of SDN Pertiwi, SDN Polisi 1, SDN Kebon Pedes 1, and SDN Kebon Pedes 5 who have volunteered to participate in this research.

\section{REFERENCES}

, Badan Standar Nasional Pendidikan. (2013). Standar Kompetensi dan Kompetensi Dasar Mata Pelajaran Ilmu Pengetahuan Alam untuk Sekolah Dasar /Madrasah Ibtidaiyah kelas 1 s.d kelas 6 Jakarta.

Alseweed, M. A. (2013). Students' achievement and attitudes toward using traditional learning, blended learning, and virtual classes learning in teaching and learning at the university level. Studies in Literature and Language, 6(1), 65-73.

Alzahrani1, Majed G \& O'Toole, John M. (2017). The Impact of Internet Experience and Attitude on Student Preference for Blended Learning. Journal of Curriculum and Teaching. Vol. 6, No. 1.

Archambault, I., Janosz, M., Morizot, J., \& Pagani, L. (2009). Adolescent behavioral, affective, and cognitive engagement in school: Relationship to dropout. Journal of School Health, 79(9), 408415.

Arnold, B. (2015). The Double-Helix Model: Proactive Learning Environmrnt Design. 5th Annual International conference on Education and e-learning. ISSN: 2251-1814. Doi: 10.5176/22511814_Eel 15.40.109-116.

Bell, R. L., Smetana, L., \& Binns, I. (2005). Simplifying inquiry instruction. The Science Teacher. 72(7), 30-33.

Bhattacharyya, S., Mead, Tim P., Junot, M., \& Welch, Adam. (2013). Effectiveness of Science 
Method Teaching in Teacher Education: A longitudinal case study. Electronic Journal of Science Education. Vol. 17, No. 2. 2-23.

Bruner, J. (1965). The process of education. Cambridge, MA: Harvard University Press.

Carin, Arthur A. and Robert B. Sund. (1975). Teaching Science Trought Discovery. Columbus, Ohio: Charless E. Merrill Publishing Co.

Celikler, D., Gunes M. H., \& Sendil, K. (2006). The effect of constructivist method on achivement of student in metal and nonmetal topics. Ahi Evran University Journal of Kirsehir Education Faculty, 7(2), 51-59.

Cohen, L. \& Manion, L. (1994). Research Methods in Education. London: Routeledge and Kegan Paul.

Colburn, A. (2004). Inquiring scientists want to know. Educational Leadership, 62, 63-66.

Conant,James B. (1951). Science and Common Sense (New Haven, Conn.: Yale University Press.

Daşdemir, İkramettin. The Effect of the 5E Instructional Model Enriched with Cooperative Learning and Animations on Seventh-Grade Students' Academic Achievement and Scientific Attitudes. International Electronic Journal of Elementary Education, September 2016, 9(1), 21-38.

Dorph, Rena, Cannady, Matthew A. \& Schunn, Christian. (2016) How Science Learning Activation Enables Success for Youth in Science Learning. Electronic Journal of Science Education.Vol. 20, No. 8. 49-85.

Duffy, T. M., \& Jonassen, D. H. (1991). Constructivism: new implications for instructional technology-Educational Technology, 31(5), 7-12.

Fernando, Sithara YJN \& Marikar, Faiz MMT. (2017). Constructivist Teaching/Learning Theory and Participatory Teaching Methods. Journal of Curriculum and Teaching. Vol. 6, No. 1.

Fredericks, J.A., Blumenfeld, P.C. \& Paris, A.H. (2004). School engagement: Potential of the concept, state of the evidence. School engagement. 74(1), 59-109.

Funk, H. James, et al. (1979). Learning Science Process Skills. Kerper Boulevard: Kendall/Hunt Publishing Company.

Ja'ashan, M. H. (2015). Perceptions and attitudes towards blended learning for English courses: A case study of students at University of Bisha. English Language Teaching, 8(9), 40-50.

Kadir. (2016). Statistik Terapan: Contoh dan Analisis Data dengan Program SPSS/Lisrel dalam Penelitian. Ed. Kedua. Jakarta: Rajawali Pers.

Kementerian Pendidikan dan Kebudayaan Republik Indonesia. (2013). Buku Tematik Terpadu Kurikulum 2013: Buku Siswa SD/MI Kelas IV.Jakarta: Ministry of Education and Culture of the Republic of Indonesia.

Kementerian Pendidikan dan Kebudayaan Republik Indonesia. (2013). Buku Tematik Terpadu Kurikulum 2013: Buku Guru SD/MI Kelas IV.Jakarta: Kementerian Pendidikan dan Kebudayaan Republik Indonesia.

Kementerian Pendidikan dan Kebudayaan. (2013). Kurikulum 2013 untuk Sekolah Dasar.

Koseoglu, F., \& Tumay, H., (2010). The effects of learning cycle method in general chemistry laboratory on students' conceptual change, attitude and perception. Ahi Evran University Journal of Kirsehir Education Faculty, 11(1), 279-295.

Kozma, R. B. (1991). Learning with Media. Review of Educational Research. 61(2), 179.

Lemos, Marina S. \& Veríssimo, Lurdes V. (2014). The relationships between intrinsic motivation, extrinsic motivation, and achievement, along elementary school. Procedia - Social and Behavioral Sciences, 112. 930-938.

McMillan, J. H., \& Schumacher, S. (2006). Research in Education: Evidence-Based Inquiry. Sixth Edition. Boston: Allyn and Bacon.

Newman, W, Abell, S., Hubbard, P., McDonald, J., Otaala, J., \& Martini, M. (2004). Dilemmas of teaching inquiry in elementary science methods. Journal of Science Teacher Education,15(4), 257-279.

Novak, D. J. Learning Science and The Science of Learning, Studies in Science Education, (1988). 15, 77-101.

Perrin, Michele. (2004). Inquiry-Based Pre-Engineering Activities For K4-Students. Journal of STEM Education, Vol. 5. Issue 3 and 4. July-December 2004. 29-34.

Smith, P.I. \& Ragan, T.J. (2005). Instructional Design. (3rd. ed.), Hoboken. N.J: Wiley. p. 244.

Tatli, Z.\& Ayas, A. (2011). Effect of a Virtual Chemistry Laboratory on Students' Achievement. 
Educational Technology \& Society, 16(1), 159-170.

Windschitl, M. (2002). Inquiry projects in science teacher education: What can investigative experiences reveal about teacher thinking and eventual classroom practice? Science Education, $87,112-143$.

You, S., \& Sharkey, J. (2009).Testing a developmental-ecological model of student engagement: A multilevel latent growth curve analysis. Educational Psychology, 29(6). 659-684. 